\title{
A Review of the Evidence Supporting the Vitamin D-Cancer Prevention Hypothesis in 2017
}

\author{
WILLIAM B. GRANT \\ Sunlight, Nutrition, and Health Research Center, San Francisco, CA, U.S.A.
}

\begin{abstract}
The vitamin D-cancer prevention hypothesis has been evaluated through several types of studies, including geographical ecological studies related to indices of solar ultraviolet-B $(U V B)$ dose (the primary source of vitamin $D$ for most people), observational studies related to UVB exposure or serum 25-hydroxyvitamin $D$ [25(OH)D] concentrations, laboratory studies of mechanisms, and clinical trials. Each approach has strengths and limitations. Ecological studies indirectly measure vitamin $D$ production and incorporate the assumption that vitamin D mediates the effect of UVB exposure. Findings from observational studies with long follow-up times are affected by changing $25(\mathrm{OH}) \mathrm{D}$ concentrations over time. Most clinical trials have been poorly designed and conducted, based largely on guidelines for pharmaceutical drugs rather than on nutrients. However, three clinical trials do support the hypothesis. In general, the totality of the evidence, as evaluated using Hill's criteria for causality in a biological system, supports the vitamin $D$-cancer prevention hypothesis.
\end{abstract}

The ultraviolet-B (UVB)-vitamin D-cancer hypothesis was first proposed based on a geographical ecological study of colon cancer mortality rates in the United States with respect to annual sunlight doses (1). Since then, researchers have undertaken considerable effort to understand how vitamin D affects the risk of many cancers. As of August 28, 2017, 7947 publications were listed at pubmed.gov, found by searching "vitamin D or vitamin $\mathrm{D}_{3}$ or 25 -hydroxyvitamin $\mathrm{D}$ and

This article is freely accessible online.

Correspondence to: William B. Grant, Sunlight, Nutrition and Health Research Center, PO Box 641603, San Francisco, CA 941641603, U.S.A. Tel: +1 4154091980, e-mail: wbgrant@infionline.net

Key Words: African Americans, bladder, breast, cancer, clinical trials, colorectal, disparities, ecological studies, observational studies, UVB, vitamin D, review. cancer" in the title/abstract. Several recent papers have reviewed the evidence (2-9). Some of the shortcomings noted include inconsistent findings from observational studies (6) and lack of supporting clinical trials (10). Despite 37 years and millions of dollars of research effort, the consensus on the importance of vitamin D status in reducing cancer risk and improving survival after initiation is still mixed. On one hand, supporters point to the large body of evidence including geographical ecological studies, observational studies, clinical trials, and an understanding of the mechanisms. On the other hand, doubters point to observational studies and clinical trials that failed to support the hypothesis as well as possible problems with some studies that did.

This paper reviews the epidemiological study results regarding UVB exposure and vitamin D and cancer risk along with the clinical trials of vitamin D supplementation and blackwhite disparities in cancer survival rates. The goal is to clarify how UVB exposure and vitamin D reduce cancer risk and increase survival after initiation through a narrative review.

\section{Background}

Vitamin D's role in reducing cancer risk can be determined through a variety of approaches:

- Geographical ecological studies related to indices of solar UVB doses

- Observational studies related to 25-hydroxyvitamin D [25(OH)D] concentration

- UVB exposure or oral vitamin D intake (case-control, prospective, and cross-sectional)

- Genetic polymorphisms and mechanisms

- Clinical trials

Additional support also comes from comparing cancer survival rates between black and white Americans (11).

Geographical ecological studies. Geographical ecological studies use population-averaged data on cancer and its risk- 
modifying factors, including a UVB index such as annual solar radiation $(1,12)$ solar UVB in the summer $(13)$, annual solar erythemal radiation (14), or latitude (15). Other factors often included are alcohol consumption, ethnic background, lung cancer rates (an index of both smoking and, less so, diet), socioeconomic status, and urban/rural residence (16). Although this approach is indirect in that it considers UVB exposure, factors related to solar exposure other than vitamin D production probably cannot explain the findings. According to one study in mice, UV exposure had a stronger effect in reducing progression of colorectal cancer tumors than oral vitamin $\mathrm{D}$, both of which raised $25(\mathrm{OH}) \mathrm{D}$ concentrations by the same amount (17). However, no mechanism was proposed and no further studies along that line have been conducted.

Occupational UVB exposure studies. Studying occupational exposure to UVB is another way to assess how solar UVB exposure and, presumably, vitamin D status affect cancer risk. Such exposure would occur regularly for many years and would be much higher for people with predominantly outdoor occupations than for people with predominantly indoor occupations.

Observational studies. Observational studies offer another approach to determine whether vitamin D affects cancer risk. Three types of observational studies exist: case-control (CC), prospective or nested case-control (NCC), and crosssectional. In $\mathrm{CC}$ studies, 25(OH)D concentrations are determined near the time of cancer diagnosis and compared with those of matched controls. Cross-sectional studies have the distinct disadvantage that enough time has generally passed since cancer diagnosis that serum 25(OH)D concentrations could have changed from those taken before diagnosis.

Genetic polymorphism studies. Because serum 25(OH)D concentrations change, researchers have sought alternative approaches to determine how vitamin D affects cancer risk. Most of vitamin D's action regarding cancer occurs through the hormonal metabolite of vitamin D, 1,25-dihydroxyvitamin $\mathrm{D}$, affecting gene expression through activating vitamin $\mathrm{D}$ receptors (VDRs). Therefore, studies of cancer risk with respect to VDR polymorphisms can be useful.

Clinical trials. Clinical trials designed to show that vitamin $D$ reduces cancer risk have largely been based on the pharmaceutical drug model: that the trial is the only source of the agent; and that there is a linear dose-response relationship. Unfortunately, that study model is not appropriate for vitamin D because vitamin D does not satisfy the two basic assumptions of drug trials: people obtain vitamin D from UVB exposure, diet, and supplements, and that the dose-response relationship is not linear. Serum $25(\mathrm{OH}) \mathrm{D}$ concentrations vary widely by individual for the same vitamin D supplement amount (18), in part because of different body mass indicies indices (19) and in part due to different baseline $25(\mathrm{OH}) \mathrm{D}$ concentrations. In addition, many of the trials enrolled people with relatively high baseline $25(\mathrm{OH}) \mathrm{D}$ concentrations or did not give high enough vitamin D doses to significantly change $25(\mathrm{OH}) \mathrm{D}$ concentrations along the health outcome-25(OH)D concentration relationship.

\section{Results}

Geographical ecological studies. For many cancers, mortality rates in the U.S.A. are lowest in the southwestern states and highest in the northeastern states (20). According to later ecological studies, 22 cancers have incidence or mortality rates inversely correlated with solar UVB doses in the U.S. for whites (which includes Hispanic heritage): bladder, breast, colon, endometrial, esophageal, gallbladder, kidney, laryngeal, liver, lung, oral, ovarian, pancreatic, pharyngeal, prostate, rectal, small intestine, thyroid, vulvar cancer, Hodgkin's lymphoma, leukemia, and non-Hodgkin's lymphoma (12, 13, 16, 21-23). For black Americans, the cancers include bladder, breast, colon, gastric, lung, ovarian, pancreas, and rectal $(13,139)$. Findings from ecological studies in the U.S. and several other midlatitude countries are reviewed in (2).

According to U.S.A. ecological studies conducted using cancer incidence rates after 1999, UV doses significantly inversely correlated with 14 cancers: bladder, brain, breast, colon, endometrial, hepatocellular carcinoma, lung, ovarian, pancreas, pleura, prostate, rectal, and thyroid cancer as well as non-Hodgkin's lymphoma (mainly diffuse large B-cell lymphoma) (12, 14, 22, 24). For cancer mortality rates, inverse correlations were evident only for bladder, endometrial, esophageal, lung, and ovarian cancer as well as leukemia and non-Hodgkin's lymphoma (12). However, researchers in two studies found no inverse correlations between solar UVB dose or exposure and incidence of breast cancer after $2000(14,22)$. As my letter to the editor regarding the Zamoiski study pointed out (25), the inverse correlation between solar UVB dose for July 1992 and breast cancer mortality rates for white women started to decrease in the 1980-1984 period, with a rapid decrease for 19901994. The decreases can be attributed to increased sun avoidance and use of sunscreen, increasing rates of obesity, and widespread screening and improved treatment for some of those cancers. Obesity lowers $25(\mathrm{OH}) \mathrm{D}$ concentrations, possibly through volumetric dilution (26). Several factors, including those mentioned as well as use of daily sunlight rather than solar UVB in summer, may explain why no inverse correlations were apparent for mortality rates for 
breast, colon, gallbladder, oral cavity and pharynx, pancreas, rectal, stomach, and thyroid cancer (12).

Although ecological studies are generally adjusted for other cancer risk-modifying factors, they are generally considered to generate hypotheses rather than show causality. For example, the analysis may not include all relevant cancer risk-modifying factors. In addition, nonvitamin $D$ effects of sunlight that affect cancer risk could be present. However, only one study, in mice, supports the role of non-vitamin D effects in the progression of cancer but not in its initiation (17).

Occupational UVB exposure studies. A study related to occupational UVB exposure was based on cancer incidence data for 2.8 million 30- to 64-year-old residents identified in censuses of 1960 to 1990 of five Nordic countries and followed up through cancer registries until about 2005 (27). The cases were assigned to one of 53 occupational categories or one group of economically inactive people. In the study, lip cancer standardized incidence ratio (SIR) less lung cancer SIR was the index chosen for personal long-term UVB exposure (28). Neither melanoma nor nonmelanoma skin cancer was judged to be an appropriate index of UVB exposure. Those cancers are linked to both UVA and UVB exposure, and occupational exposure is not a risk factor for melanoma (29). In fact, melanoma SIR was significantly inversely correlated with the UVB index for males, as was the nonmelanoma skin cancer SIR to a lesser extent. As expected, occupations with the highest expected outdoor work - farmers, forestry workers, and gardeners - had the lowest cancer SIRs. Occupations such as beverage workers, drivers, tobacco workers, and wait staff were at the high end. However, some people in those categories probably had cancer risk factors such as consuming alcohol and smoking in addition to lower $25(\mathrm{OH}) \mathrm{D}$ concentrations. For men, the UVB index was significantly inversely correlated with 14 internal cancers: bladder, breast, colon, gallbladder, kidney, laryngeal, liver, lung, oral, pancreatic, pharyngeal, prostate, rectal, and small intestine. For women, the same UVB index was inversely correlated with bladder, breast, and colon cancer. Because women generally wear lipstick, the UVB index developed for males was used for them.

Observational studies. Two recent papers reviewed the findings from observational studies on cancer incidence and mortality rates $(6,8)$. One paper concluded that reasonable evidence exists that prospective and NCC studies generally find higher $25(\mathrm{OH}) \mathrm{D}$ concentrations associated with reduced incidence of bladder, colorectal, and lung cancer, but results for breast and pancreas cancer were mixed (6). The other paper reported meta-analyses of cancer progression and mortality with respect to $25(\mathrm{OH}) \mathrm{D}$ concentration at time of diagnosis, with findings of significant reductions in progression for breast, hematological, skin, and overall cancer, and cancer-specific survival for breast, colorectal, gastric, hematological, kidney, liver, lung, ovarian, and overall cancer (8).

In NCC and prospective studies, $25(\mathrm{OH}) \mathrm{D}$ concentration in the blood is measured at enrollment. One problem with such studies is that $25(\mathrm{OH}) \mathrm{D}$ concentrations change with time because of seasonal variations in solar UVB doses and changes in diet, lifestyle, and supplementation. As a result, the observed effect of higher $25(\mathrm{OH}) \mathrm{D}$ concentration generally decreases with longer follow-up times, as shown for breast and colorectal cancer $(3,30)$ and all-cause mortality rate (31).

The CC study's primary advantage is that the values of the factors are obtained near the time of disease diagnosis. In general, that approach results in stronger associations between factor values and health outcomes. That proximity also is thought to be a disadvantage by many who assume that the disease state can affect the factor values. However, no studies have shown that having early-stage undiagnosed cancer affects $25(\mathrm{OH}) \mathrm{D}$ concentrations. Investigating the relationship between $25(\mathrm{OH}) \mathrm{D}$ concentration and breast cancer stage at time of diagnosis is one way to test whether $25(\mathrm{OH}) \mathrm{D}$ concentration changes as a result of cancer initiation and progression. From the abstract for one such study: "In fully adjusted logistic regression models, the ORs $(95 \%$ [confidence intervals $\{\mathrm{CIs}\}]$ ) for the association between vitamin D deficiency and Stage II and III cancers were 0.85 $(0.59-1.22)$ and $1.23(0.71-2.15)$, respectively $\left(P_{\text {trend }}=0.59\right)$, compared to Stage I. This study confirms previous work regarding the correlates of $25(\mathrm{OH}) \mathrm{D}$ concentrations but does not provide support for an association between vitamin D status and breast cancer stage."(32). A later study in China supported those results (33). Because most breast cancer tumors are diagnosed at stages I and II, most CC studies should not be subject to a cancer effect on $25(\mathrm{OH}) \mathrm{D}$ concentration. Indeed, for breast cancer, the $25(\mathrm{OH}) \mathrm{D}$ concentration-incidence relations from $11 \mathrm{CC}$ studies from seven countries are practically coincident; however, researchers conducting prospective studies with follow-up times longer than 3-4 y generally do not find a significant difference in incidence with respect to $25(\mathrm{OH}) \mathrm{D}$ concentration (3). Evidence was given that breast cancer quickly goes from undetectable to detectable. One supporting factor is that mammography is recommended annually. The other is that breast cancer has seasonal variations in incidence rates, higher in spring and fall than in summer and winter (34). The authors proposed that vitamin D reduces breast cancer risk in summer, whereas melatonin does so in winter. Thus, using CC studies to investigate how vitamin D status affects breast cancer incidence seems justified.

One overlooked problem regarding observational studies that useserum $25(\mathrm{OH}) \mathrm{D}$ concentrations is that animal 
Table I. Cancer incidence rates with respect to $25(\mathrm{OH})$ D concentrations from meta-analyses.

\begin{tabular}{|c|c|c|c|c|c|}
\hline Cancer & Type of study & $\mathrm{N}$ & $\begin{array}{l}\text { Low, high } 25(\mathrm{OH}) \mathrm{D} \\
\text { (nmol/L) }\end{array}$ & $\begin{array}{l}\text { HR }(95 \% \mathrm{CI}) \text { high } v s . \text { low } \\
25(\mathrm{OH}) \mathrm{D} \text { conc. }\end{array}$ & Reference \\
\hline All & MA & 7 & Increase of 50 & $0.89(0.81-0.97)$ & $(40)$ \\
\hline Bladder & $\mathrm{MA}, \mathrm{CC}$ & 3 & & $0.70(0.56-0.88)$ & (41) \\
\hline Bladder & MA, NCC & 5 & & $0.80(0.67-0.94)$ & (41) \\
\hline Breast & $\mathrm{MS}, \mathrm{CC}$ & 5 & Increase of 50 & $0.60(0.54-0.67), p=0.001$ & $(42)$ \\
\hline Breast & $\mathrm{MS}, \mathrm{NCC}$ & 4 & Increase of 50 & $0.92(0.82-1.02), p=0.10$ & $(42)$ \\
\hline Breast & MA, Pr & 14 & Quantiles & $0.92(0.83-1.02)$ & (43) \\
\hline Breast & $\mathrm{MA}, \mathrm{CC}$ & 11 & $<25,>125$ & 0.23 & (5) \\
\hline Colorectal & MA & 16 & $<13$ vs. $>125$ & $0.4(0.2-1.0)$ & (44) \\
\hline Colorectal & MA & 15 & $>50 \mathrm{vs} .<50$ & $0.67(0.59-0.76)$ & (44) \\
\hline Kidney & MA, NCC, $\mathrm{Pr}$ & 9 & Quantiles & $0.79(0.69-0.91)$ & (45) \\
\hline Lung & MA, NCC & 13 & $20 v s .53$ & $\mathrm{RR}=0.88(0.78-0.97)$ & $(46)$ \\
\hline Lung & MA & 8 & Quantiles & $0.72(0.61-0.85)$ & (47) \\
\hline NHL & MA & 9 & Quantiles & $\mathrm{OR}=1.03(0.84-1.26)$ & $(48)$ \\
\hline Ovarian & MA & 10 & Increase of 50 & $0.83(0.63-1.08) p=0.17$ & $(49)$ \\
\hline Pancreatic & MA & 9 (pub 2006-2012) & Quantiles & $1.14(0.90,1.45)$ & $(50)$ \\
\hline Pancreatic & MA & 5 (pub 2010-2015) & Quantiles & $1.02(0.68-1.57)$ & $(51)$ \\
\hline Prostate & MA, NCC & 16 & Quantiles & $1.17(1.08,1.27)$ & $(52)$ \\
\hline Stomach & MA & 7 & Quantiles & $0.92(0.74-1.14), P_{\text {trend }}=0.43$ & (53) \\
\hline
\end{tabular}

CC: Case-control study; CI: confidence interval; CS: cancer specific; HR: hazard ratio; MA: meta-analysis; NCC: nested case-control study; NHL: non-Hodgkin's lymphoma; OR: odds ratio; Pr: prospective study; RR: relative risk; Vit D: oral vitamin D.

products such as meat, eggs, and fish are important dietary sources of vitamin $\mathrm{D}$, sometimes in the form of $25(\mathrm{OH}) \mathrm{D}$ in meat. Meat eaters in the UK had mean 25(OH)D concentrations of $77 \mathrm{nmol} / 1$, whereas vegans had $56 \mathrm{nmol} / 1$ (35). Meat consumption, especially of red and processed meat, is an important risk factor for many cancers $(36,37)$, as is egg consumption (38). However, fish consumption, a source of omega- 3 fatty acids and vitamin $\mathrm{D}$, reduces the risk of several cancers (36), including breast cancer (39). Because observational studies of $25(\mathrm{OH}) \mathrm{D}$ concentration and cancer seldom consider diet, it could play an important role in cancer risk, especially if dietary factors change during a long follow-up study. Diet also could be an important consideration in comparing populations with different dietary factors.

Despite observational studies' inherent problems, many have yielded significant inverse correlations between $25(\mathrm{OH}) \mathrm{D}$ concentration and cancer risk. Tables I, II, III, and IV present the most recent findings from observational studies regarding cancer incidence, progression, survival, and mortality rates with respect to $25(\mathrm{OH}) \mathrm{D}$ concentrations. Tables I and III present results for meta-analyses, and Tables II and IV for single studies for types of cancer for which meta-analyses have not been conducted. Meta-analyses report significant inverse correlations between serum $25(\mathrm{OH}) \mathrm{D}$ concentration and incidence of all, bladder, breast, colorectal, kidney, and lung cancer. Single studies report the same for brain (glioma), cervical, esophageal squamous-cell carcinoma, gastric adenocarcinoma, head and neck, larynx and hypopharynx, liver, oral cavity and gum, ovarian, and pancreatic cancer.

Negative observational studies. In several observational studies, either no correlation or a direct correlation was evident between serum $25(\mathrm{OH}) \mathrm{D}$ concentration and cancer incidence rates. A careful consideration of those studies' parameters indicates the presence of factors that call the results into question. Several of those studies are discussed here.

The Cohort Consortium Vitamin D Pooling Project of Rarer Cancers (VDPP). The Vitamin D Pooling Project of Rarer Cancers (VDPP) combined data on cancer incidence with respect to baseline $25(\mathrm{OH}) \mathrm{D}$ concentration from 10 studies from China, Finland, and the United States (81). The number of cancer cases varied from 775 for kidney cancer to 1353 for lymphoma. Median follow-up times varied from 2.1 to $10.8 \mathrm{y}$, with a median study time of $4.6 \mathrm{y}$. Results were given for endometrial, kidney, ovarian, pancreatic, and upper gastrointestinal (esophageal and gastric) cancer and for lymphoma. The only non-significant finding for six quantiles of $25(\mathrm{OH}) \mathrm{D}$ concentration was an increased risk for pancreatic cancer at the highest quantile. In other studies, reduced risk was evident for gastric (59), kidney (45), and ovarian cancer (82). Why no inverse correlations with respect to $25(\mathrm{OH}) \mathrm{D}$ concentration was present for those cancers in the VDPP study is unclear. 
Table II. Cancer incidence rates with respect to $25(\mathrm{OH}) D$ concentrations from single studies.

\begin{tabular}{|c|c|c|c|c|c|c|}
\hline Cancer & $\begin{array}{l}\text { Type of } \\
\text { study }\end{array}$ & $\begin{array}{l}\text { Follow-up } \\
\text { period (y) }\end{array}$ & $\begin{array}{l}\mathrm{N} \text { cases, } \\
\text { controls }\end{array}$ & $\begin{array}{c}\text { Low, high } 25(\mathrm{OH}) \mathrm{D} \\
(\mathrm{nmol} / \mathrm{L})\end{array}$ & $\begin{array}{l}\text { HR }(95 \% \mathrm{CI}) \text { high } v s . \text { low } \\
25(\mathrm{OH}) \mathrm{D} \text { conc. }\end{array}$ & Reference \\
\hline All & Trial & $1-2$ & & 75 to $138,<75$ & $0.65(0.44-0.97)$ & $(54)$ \\
\hline Brain (glioma) & NCC & 15 (med) & 592,1112 & $>66,>2 \mathrm{yr}$ prior & $\mathrm{OR}=0.59(0.38-0.91)$ & (55) \\
\hline Cervical & $\mathrm{CC}$ & 0 & 333,1665 & $\begin{array}{c}(\text { Vit D) }<162 \mathrm{IU} / \mathrm{d} \\
v s .>291 \mathrm{IU} / \mathrm{d}\end{array}$ & $0.64(0.43-0.94), P_{\text {trend }}=0.01$ & $(56)$ \\
\hline Endometrial & $\operatorname{Pr}$ & $20(\max )$ & 572,572 & Low, high quintiles & $1.00(0.73-1.36), P_{\text {trend }}=0.33$ & $(57)$ \\
\hline Esophageal SCC & $\mathrm{CC}$ & 0 & 106,108 & $<40,>70$ & $0.37(0.18-0.76), P_{\text {trend }}=0.007$ & (58) \\
\hline Gastric adenocarcinoma & Retro & 0 & 49,49 & Vitamin $\mathrm{D}<50$ & $0.11(0.05-0.20), p<0.0001$ & (59) \\
\hline Head and neck & $\operatorname{Pr}$ & 6.3 (mean) & 350,350 & Doubling & $0.70(0.56-0.880, p=0.001$ & $(60)$ \\
\hline Hepatocellular carcinoma & $\operatorname{Pr}$ & 6 (mean) & 138,138 & Mean, 34 vs. 74 & $0.51(0.26-0.99), p=0.04$ & (61) \\
\hline Larynx and hypopharynx & $\operatorname{Pr}$ & 6.3 (mean) & 144,144 & Doubling & $0.55(0.39-0.78), p<0.001$ & $(60)$ \\
\hline Lymphoma, chronic lymphocytic & $\mathrm{NCC}$ & 7.1 (mean), $>2$ & 161,161 & $<43,>72$ & $\begin{array}{c}0.40(0.18,0.90) \\
P_{\text {trend }}=0.05\end{array}$ & $(62)$ \\
\hline Lymphoma, chronic lymphocytic & $\mathrm{NCC}$ & 7.1 (mean) & 202,202 & $<43,>72$ & $\begin{array}{c}0.82(0.43,1.61) \\
P_{\text {trend }}=0.86\end{array}$ & (62) \\
\hline Oral cavity and gum & $\operatorname{Pr}$ & 6.3 (mean) & 108,108 & Doubling & $0.60(0.43-0.87), p=0.005$ & $(60)$ \\
\hline Ovarian & $\mathrm{CC}$ & 0 & 46,106 & $<50.5$ & $\begin{array}{c}\text { Area under ROC curve } \\
0.81(0.71-0.88)\end{array}$ & (63) \\
\hline Thyroid & Retro & 0 & 212 & $<37.5,>37.5$ & $0.50(0.38,0.93)$ & (64) \\
\hline Vulvar & $\mathrm{CC}$ & 0 & 24 & & Not significant & $(65)$ \\
\hline
\end{tabular}

CC: Case-control study; FU: follow-up; HR: hazard ratio; IPRT: intratumoural periglandular reaction tumor; MA: meta-analysis; med, median; NCC: nested case-control study; NHL: non-Hodgkin's lymphoma; Pr: prospective study; Retro, retrospective; ROC: receiver operating characteristics; SCC: squamous-cell carcinoma; Vit D: oral vitamin D.

Table III. Cancer survival with respect to $25(\mathrm{OH}) \mathrm{D}$ concentration at time of diagnosis from meta-analyses.

\begin{tabular}{|c|c|c|c|c|c|}
\hline Cancer & Study & $\mathrm{N}$ & $\begin{array}{c}\text { Low, high } \\
25(\mathrm{OH}) \mathrm{D}(\mathrm{nmol} / \mathrm{L})\end{array}$ & $\begin{array}{l}\text { HR high } v s . \text { low } \\
25(\mathrm{OH}) \mathrm{D} \text { conc. }\end{array}$ & Reference \\
\hline All (mortality) & MA, CS & 16 & Increase of 50 & $0.83(0.71-0.96)$ & $(40)$ \\
\hline All, males (mortality) & MA, CS & 16 & Increase of 50 & $0.92(0.65-1.32)$ & (40) \\
\hline All, females (mortality) & MA, CS & 16 & Increase of 50 & $0.76(0.60-0.98)$ & (40) \\
\hline Breast & MA, OS & 5 & Fixed effects model & $0.67(0.56-0.79), p<0.001$ & (66) \\
\hline Breast & MS, CS & 4 & & $0.58(0.40-0.85)$ & (43) \\
\hline Breast & MS, OS & 6 & & $0.61(0.48-0.79)$ & (43) \\
\hline Colorectal & MA, CS & 4 & Quintiles & $\mathrm{POR}=0.63, p<0.0001$ & (67) \\
\hline Colorectal & MA, CS & 3 & Quartiles & $0.65(0.47-0.88)$ & $(68)$ \\
\hline Colorectal & MA, OS & 5 & Quartiles & $0.55(0.33-0.91)$ & (68) \\
\hline Hematological & MA, RFS & 12 & $\begin{array}{l}\text { Low } 25(\mathrm{OH}) \mathrm{D} \text { : } \\
20 \text { to } 63\end{array}$ & $0.69(0.59-0.80), p<0.001$ & (69) \\
\hline Hematological & MA, OS & 15 & $"$ & $0.54(0.45-0.65), p<0.001$ & (69) \\
\hline Leukemia & MA, RFS & 12 & $"$ & $0.57(0.44-0.75), p<0.001$ & (69) \\
\hline Leukemia & MA, OS & 12 & $"$ & $0.46(0.33-0.65), p<0.001$ & (69) \\
\hline Lung & MA, OS & 4 & Quartiles & $0.75(0.30-1.86)$ & (68) \\
\hline Lung & MA, CS survival & 4 & & $1.01(0.87-1.18)$ & $(47)$ \\
\hline Lung & MA, CS mortality & 3 & & $0.38(0.28-0.54)$ & (47) \\
\hline Lymphoma & MA, RFS & 12 & $\begin{array}{l}\text { Low } 25(\mathrm{OH}) \mathrm{D} \text { : } \\
20 \text { to } 63\end{array}$ & $0.80(0.65-0.98), p=0.04$ & (69) \\
\hline Lymphoma & MA, OS & 15 & $"$ & $0.51(0.39-0.68), p<0.001$ & (69) \\
\hline Lymphoma & MA. CS & 7 & Quartiles & $0.48(0.36-0.64)$ & (68) \\
\hline Lymphoma & MA. OS & 7 & Quartiles & $0.50(0.36-0.68)$ & (68) \\
\hline Pancreatic & MA, OS & 5 & $<50$ vs. $>75$ & $0.62(0.44-0.86), p=0.02$ & (70) \\
\hline Pancreatic & MA, CS & 5 & Highest $v s$. lowest & $0.81(0.68-0.96)$ & (51) \\
\hline
\end{tabular}

HR: Hazard ratio; MA: meta-analysis; POR: pooled odds ratio; Pr: prospective study; RFS: recurrence-free survival. 
Table IV. Cancer progression or survival with respect to $25(\mathrm{OH}) \mathrm{D}$ concentration at time of diagnosis from individual studies.

\begin{tabular}{|c|c|c|c|c|c|}
\hline Cancer & Study & $\begin{array}{l}\mathrm{N} \text { cases, } \\
\text { controls }\end{array}$ & $\begin{array}{c}\text { Low, high } \\
25(\mathrm{OH}) \mathrm{D}(\mathrm{nmol} / \mathrm{L})\end{array}$ & $\begin{array}{l}\text { HR high } v s . \text { low } \\
25(\mathrm{OH}) \mathrm{D} \text { concn. }\end{array}$ & Reference \\
\hline Bladder & $\mathrm{Pr}, \mathrm{OS}$ & 4126 & $<50$ vs. $>50$ & Mos. survived: 69.9 vs. 63.3 & (71) \\
\hline Bladder & $\mathrm{Pr}, \mathrm{OS}$ & 4126 & $25(\mathrm{OH}) \mathrm{D}$ tests: $<3 v s . \geq 3$ & Mos. survived: 90.6 vs. 39.7 & (71) \\
\hline Head and neck & Pr, OS (primarily CS) & 87,87 & Doubling & $0.71(0.53-0.96), p=0.02$ & $(60)$ \\
\hline Kidney & Pr, CS & 152 & $\begin{array}{c}\text { Season-adjusted quartiles, } \\
\text { median }=43\end{array}$ & $0.70(0.39-1.24), p=0.53$ & (72) \\
\hline Kidney & $\mathrm{Pr}, \mathrm{OS}$ & 203 & $\begin{array}{c}\text { Season-adjusted quartiles, } \\
\text { median }=43\end{array}$ & $0.59(0.35-1.00), p=0.03$ & $(72)$ \\
\hline Liver & $\operatorname{Pr}$ & 200 & $<25$ vs. $>25$ & $0.50(0.28-0.88), p=0.02$ & (73) \\
\hline Lymphoma, follicular & SWOG, Pr, 5.4 y, PFS & 183 & $<50,>50$ & $1.97(1.10-3.53)$ & (74) \\
\hline Lymphoma, follicular & SWOG, Pr, 5.4 y, OS & 183 & $<50,>50$ & $4.16(1.66-10.44)$ & (74) \\
\hline Lymphoma, follicular & LYSA, Pr, 6.6 y, PFS & 240 & $<25,>25$ & $1.50(0.93-2.42)$ & (74) \\
\hline Lymphoma, follicular & LYSA, Pr, 6.6 y, OS & 240 & $<25,>25$ & $1.92(0.72-5.13)$ & (74) \\
\hline Melanoma & & & & & $(75)$ \\
\hline Ovarian & Pr, PFS & 491,650 & Per 10 & $0.98(0.93-1.03)$ & (76) \\
\hline Ovarian & $\mathrm{Pr}, \mathrm{OS}$ & 435,670 & Per 10 & $0.93(0.88-0.99)$ & (76) \\
\hline Prostate & $\operatorname{Pr}, \mathrm{CS}$ & 1000 & $<20,>52$ & $0.72(0.52-0.99), P_{\text {trend }}=0.006$ & (77) \\
\hline Prostate & Pr, CS & 2282 & $<50,>50$ & $1.20(0.97-1.48)$ & (78) \\
\hline Prostate & Pr, OS & 2282 & $<50,>50$ & $1.25(1.05-1.50)$ & (78) \\
\hline Stomach & Pr, OS & 197 & $<50$ vs. $>50$ & $0.59(0.37-0.91), p=0.02$ & (79) \\
\hline Thyroid & & 820 & 20,58 & $1.72(0.46,6.41)$ & $(80)$ \\
\hline
\end{tabular}

CaCo: Case-cohort; CS: cancer specific; HR: hazard ratio; LYSA: Lymphoma Study Association; MA: meta-analysis; OS: overall survival; PFS: progression-free survival; POR, pooled odds ratio; Pr: prospective study; Retro: retrospective; SWOG; Southwest Oncology Group.

Many studies examining the relation between cancer incidence and $25(\mathrm{OH}) \mathrm{D}$ concentration were conducted using results for participants in the Finnish Alpha-Tocopherol, Beta-Carotene Cancer Prevention (ATBC) Study. That randomized, double-blind, placebo-controlled primary prevention trial was undertaken to determine whether supplementation with $\alpha$-tocopherol, $\beta$-carotene, or both would reduce the incidence of lung and other cancers in male smokers. A total of 29,133 men aged 50-69 y who smoked five or more cigarettes daily were randomly assigned to receive $\alpha$-tocopherol (50 $\mathrm{mg}), \beta$-carotene $(20 \mathrm{mg}), \alpha$ tocopherol and $\beta$-carotene, or a placebo daily for 5-8 y (median, 6.1 y) (83). Thus, the population may not be representative of most populations. A second problem was that cancer cases were ascertained up to $20 \mathrm{y}$ after blood draw. Long follow-up times reduce the correlation between cancer incidence and $25(\mathrm{OH}) \mathrm{D}$ concentration (3). Two studies were reported for colon and rectal cancer. In the first one, with a follow-up period up to $8 \mathrm{y}$, an inverse correlation was found between $25(\mathrm{OH}) \mathrm{D}$ concentration and incidence of distal colon cancer and rectal cancer (84). In the second one, for the period 1999-2005, using 25(OH)D concentrations from 1985 to 1988 , colon cancer cases were directly correlated with $25(\mathrm{OH}) \mathrm{D}$ concentration, whereas no correlation was found for rectal cancer (85). In a study with a follow-up period up to $16 \mathrm{y}$, a direct correlation was found for pancreatic cancer at the highest $25(\mathrm{OH}) \mathrm{D}_{2}$ plus $25(\mathrm{OH}) \mathrm{D}_{3}$ quantile (86). Thus, long follow-up time may have adversely affected the results.

A related study was conducted in the U.S. (87). One hundred eighty-four incident cases of pancreatic adenocarcinomas occurred between 1994 and 2006 (followup to $11.7 \mathrm{y}$; median, $5.4 \mathrm{y}$ ). Although no significant correlation was found between $25(\mathrm{OH}) \mathrm{D}$ concentration and incidence of pancreatic cancer, an effect was found depending on whether the participants lived in areas with low or high residential UVB doses: for people living in lowdose regions, "higher compared with lower $25(\mathrm{OH}) \mathrm{D}$ concentrations were positively associated with pancreatic cancer (compared with first quintile, the ORs for each respective quintile were $2.52,2.33$, and 4.03 ; 95\% CI, 1.38 11.79), whereas among subjects with moderate to high residential UBV exposure, 25(OH)D concentrations were not associated with pancreatic cancer." The 25(OH)D concentrations reported in both that study and the Finnish study were a combination of $25(\mathrm{OH}) \mathrm{D}_{2}$ and $25(\mathrm{OH}) \mathrm{D}_{3}$. In a later study, adults living in the northern U.S. were more likely to have $25(\mathrm{OH}) \mathrm{D}_{2}$ concentrations than those living in the central and southern regions (88). Vitamin $\mathrm{D}_{2}$ appears to have adverse effects, according to a review of vitamin D supplementation and mortality rate (89). Thus, the higher $25(\mathrm{OH}) \mathrm{D}_{2}$ concentrations in both the northern U.S. and 
Finland may have contributed to the findings of direct correlations between $25(\mathrm{OH}) \mathrm{D}$ concentration and incidence of pancreatic cancer. For more discussion of pancreatic cancer $(51,90)$.

Esophageal cancer. In studies of esophageal and gastric cancer incidence in China, direct correlations with $25(\mathrm{OH}) \mathrm{D}$ concentration were evident for men but not women (91). The Chen study was conducted in LinXian. A later review noted that LinXian was a high-risk region for esophageal cancer and listed the following factors: drinking very hot and salted tea, boiled with milk; a diet rich in meat - especially salted, dry, and/or smoked meat - and dairy products; a diet poor in fresh fruit and vegetables; poor oral hygiene; and infection with human papillomavirus (92). Thus, studies conducted there should not be considered representative of outcomes expected elsewhere.

Prostate cancer. Findings for prostate cancer with respect to solar UVB doses and serum 25(OH)D concentration differ from those for many other cancers such as breast and colon. The geographical variation of prostate cancer mortality rate in the U.S.A. indicates highest rates in the northwest and lowest rates in the southeast, whereas most cancers have highest rates in the northeast and lowest rates in the southwest (20). One report links high sun exposure to increased risk (93). Some indication of a U-shaped relationship is evident between $25(\mathrm{OH}) \mathrm{D}$ concentration and incidence of prostate cancer, with both low and high concentrations associated with increased risk (94). A metaanalysis of 21 studies supported that finding (52). Part of the explanation may have to do with calcium. Higher intake of nonfat dairy and calcium is a risk factor (95). Vitamin D increases calcium absorption, but people with genetically reduced calcium absorption have a lower risk of prostate cancer (96).

Genetic polymorphism studies. According to a review of $V D R$ polymorphism studies through the end of 2016, several studies have looked at the association of VDRs with incidence of breast, colorectal, esophageal, hepatocellular, lung, ovarian, prostate, renal, and thyroid cancer (97). However, the findings regarding specific cancers are sometimes contradictory and often limited in scope, precluding definitive conclusions. To date, only one $V D R$ polymorphism has been found significantly associated with cancer progression in a meta-analysis, [Rs7975232 (ApaI)], and two with cancer survival [Rs7975232 (ApaI)] and [Rs 1544410 (BsmI)] (8). None was significantly correlated with any specific cancer.

Mendelian randomization studies also have been used to assess whether vitamin D may be causally linked to reduced risk of various diseases. Such studies examine the correlations of genetic polymorphisms of genes responsible for circulating $25(\mathrm{OH}) \mathrm{D}$ concentrations: $C Y P 2 R 1$, the main 25-hydroxylase of vitamin D; $G C$, coding for the vitamin Dbinding protein that transports $25(\mathrm{OH}) \mathrm{D}$ and other metabolites in blood; and $C Y P 24 A 1$, which 24-hydroxylates both 25(OH)D and the hormone (98). Mendelian randomization studies have offered support for vitamin D in reducing risk of colorectal cancer (99), risk of ovarian cancer $(100,101)$, and risk of all-cancer mortality rate (102).

Mechanisms. The mechanisms whereby vitamin D reduces cancer risk and increases survival are well known. They include effects on cellular differentiation, proliferation, and apoptosis as well as reduced angiogenesis around tumors and inhibition of metastasis $(2,7,9,10,103-105)$.

Clinical trials. Pharmaceutical drugs require placebocontrolled, double-blind clinical trials to assess efficacy and investigate short-term adverse effects. However, drug companies know how to engineer clinical trials to show beneficial effects while ignoring the findings regarding adverse effects - some of which may take years to uncover (106). Nutritional compounds such as vitamin D are not well suited for clinical trials because the pharmaceutical drug trial assumptions are not appropriate and vitamin D clinical trials have generally not supported observational studies that report beneficial effects of higher 25(OH)D concentrations (107).

Nonetheless, three vitamin $\mathrm{D}_{3}$-plus-calcium clinical trials have shown beneficial effects in reducing cancer incidence. The first one involved postmenopausal women living in Nebraska who were given $1,100 \mathrm{IU} / \mathrm{d}$ of vitamin $\mathrm{D}_{3}$ plus $1,450 \mathrm{mg} / \mathrm{d}$ of calcium, $1,450 \mathrm{mg} / \mathrm{d}$ of calcium, or placebo. "When analyzed by intention to treat, cancer incidence was lower in the $\mathrm{Ca}+\mathrm{D}$ women than in the placebo control subjects $(p<0.03)$. With the use of logistic regression, the unadjusted relative risks (RR) of incident cancer in the $\mathrm{Ca}+$ $\mathrm{D}$ and Ca-only groups were $0.402(p=0.01)$ and 0.532 $(p=0.06)$, respectively. When analysis was confined to cancers diagnosed after the first 12 months, RR for the $\mathrm{Ca}+$ D group fell to 0.232 (95\%CI: $0.09,0.60 ; p<0.005)$ but did not change significantly for the Ca-only group."(108).

The second study was a reanalysis of results from the Women's Health Initiative, in which women in the treatment arm took $400 \mathrm{IU} / \mathrm{d}$ of vitamin $\mathrm{D}_{3}$ plus $1500 \mathrm{mg} / \mathrm{d}$ of calcium."In 15,646 women $(43 \%)$ who were not taking personal calcium or vitamin D supplements at randomization, $\mathrm{CaD}$ significantly decreased the risk of total, breast, and invasive breast cancers by $14-20 \%$ and nonsignificantly reduced the risk of colorectal cancer by $17 \%$. In women taking personal calcium or vitamin $\mathrm{D}$ supplements, $\mathrm{CaD}$ did not alter cancer risk (HR: 1.06-1.26)." (109).

The third study again involved postmenopausal women living in Nebraska. This time they took 2000 IU/d of vitamin 
$\mathrm{D}_{3}$ plus $1500 \mathrm{mg} / \mathrm{d}$ of calcium or a placebo. In unadjusted Cox proportional hazards regression, the hazard ratio was 0.70 (95\% CI=0.47-1.02; $p=0.06)(54)$. However, as noted in an online supplement, women with $25(\mathrm{OH}) \mathrm{D}$ concentrations greater than $125 \mathrm{nmol} / \mathrm{L}$ at the most recent measurement before cancer diagnosis had significantly reduced cancer risk. Because the proposal did not state that the analysis would use $25(\mathrm{OH}) \mathrm{D}$ concentrations, the journal editors did not let those findings be reported in the print version of the study findings.

Those three studies were recently reviewed (5). That review pointed out that the most recent trail was near the limit of power to find a beneficial effect of vitamin D supplementation due primarily to a relatively high baseline 25(OH)D concentration $(83 \mathrm{nmol} / \mathrm{l})$ according to the 25(OHI)D concentration-breast cancer incidence relation determined from CC studies. That it failed by only one cancer case in the treatment arm was remarkable.

Two studies reported beneficial effects of vitamin $D_{3}$ supplementation for cancer patients. In one for men with low-grade prostate cancer, participants took $4000 \mathrm{IU} / \mathrm{d}$ of vitamin $\mathrm{D}_{3}$ for a year. According to the report, " 24 of 44 subjects $(55 \%)$ showed a decrease in the number of positive cores or decrease in Gleason score; five subjects $(11 \%)$ showed no change; 15 subjects (34\%) showed an increase in the number of positive cores or Gleason score." (110). Although the study used no control subjects, historical controls had a mean increased number of positive cores of about 1 over more than 18 months in comparison with a reduction of about 1.5 positive cores for the participants. The authors later reported, "These clinical results also suggest that robust and sustained vitamin $\mathrm{D}_{3}$ supplementation can reduce prostate cancer-related health disparities in AfricanAmerican men and that these health disparities are at least in part the result of widespread hypovitaminosis D within the African-American population." (111).

The other study looked at vitamin $\mathrm{D}_{3}$ supplementation for colorectal cancer patients. Those taking $4,000 \mathrm{IU} / \mathrm{d}$ of vitamin $\mathrm{D}_{3}$ had a median progression-free survival of 12.4 months, in comparison with 10.7 months for those taking $400 \mathrm{IU} / \mathrm{d}$; log-rank $p=0.03$ ). "After multivariate adjustment for prognostic variables, HR was 0.66 (95\% CI, 0.45-0.99; 2 -sided $p=0.04)$. In comparing HiVitD with LowVitD, RR was $58 \%$ vs. $63 \%(p=0.54)$ and disease control rate was $100 \%$ vs. $94 \%$ ( $p=0.05) . "(112)$.

Robert Heaney outlined how vitamin D clinical trials could be conducted. The key points include the following: 1 . Start with an understanding of the $25(\mathrm{OH}) \mathrm{D}$ concentrationhealth outcome relationship. 2. Measure 25(OH)D concentration of prospective participants and try to enroll those with concentrations near the low end of the relationship. 3. Give vitamin $\mathrm{D}_{3}$ doses high enough to raise $25(\mathrm{OH}) \mathrm{D}$ concentrations to the upper part of the relationship.
4. Measure $25(\mathrm{OH}) \mathrm{D}$ concentration again during the trial to determine the success of the dosing and assess compliance (113).

Guidelines for designing vitamin D trials more likely to find beneficial effects were outlined in two recent papers (5, 114). It was suggested that all trial outcomes be related to $25(\mathrm{OH}) \mathrm{D}$ concentrations, measured several times during the trial, with adjustments in dosing to produce desired achieved concentrations (114).

Comparing cancer survival between black and white Americans. Another way to assess vitamin D's role in cancer is to examine the disparity in cancer survival rates between black and white Americans. In the period 2001-2004, black Americans older than $40 \mathrm{y}$ had mean 25(OH)D concentrations between 35 and $43 \mathrm{nmol} / \mathrm{L}$, whereas white Americans had mean concentrations around $63-65 \mathrm{nmo} / \mathrm{L}$ (115). On the assumption that cancer survival rates have the same relationship to $25(\mathrm{OH}) \mathrm{D}$ concentrations as for breast cancer incidence, black Americans would have $60 \%$ higher cancer mortality rates than white Americans, although that estimate is highly uncertain. According to a review of the journal literature, disparities are evident for 13 cancers after consideration of socioeconomic status, stage at diagnosis, and treatment in most cases: bladder, breast, colon, endometrial, lung, ovarian, pancreatic, prostate, rectal, testicular, and vaginal cancer; Hodgkin's lymphoma; and melanoma (11). Cancer-specific mortality rates for black Americans averaged about 25\% higher than for white Americans. Of course, other lifestyle factors could also be involved. One concern is that black Americans have a different biologically available $25(\mathrm{OH}) \mathrm{D}$ concentration. That effect was believed to be a result of a different relation between total and free $25(\mathrm{OH}) \mathrm{D}$ due to a different effect of the vitamin D-binding protein (116). But a recent study dispelled that concern by showing nearly identical odds ratios for free and total 25(OH)D concentrations for colorectal cancer incidence for black Americans (117).

Summary table. Table V presents findings of ecological and observational studies regarding cancer incidence, survival, and mortality rates with respect to indices of solar UVB or $25(\mathrm{OH}) \mathrm{D}$ concentration, as well as results regarding disparities in cancer-specific survival rates between black and white Americans. The ecological study findings are taken from the review in (2). The occupational exposure results are primarily from an analysis of SIRs by occupation (28). The observational results for $25(\mathrm{OH}) \mathrm{D}$ concentrations are generally the latest meta-analysis. If no meta-analysis has been published, the most recent paper is used. The results for African Americans are from (11) along with results from later papers. The cancers are grouped into epithelial or hematopoietic (hematological) categories and arranged in descending order according to estimated incidences in 2002 
Table V. Summary table of significant inverse relationships regarding UVB dose, 25(OH)D concentration, on cancer incidence, survival, mortality rate or survival disparities for African Americans compared to white Americans.

\begin{tabular}{ccccccc}
\hline Cancer & U.S. cases, & Ecologic, & Ecologic, & Personal UVB or & $25(\mathrm{OH}) \mathrm{D}$ & $25(\mathrm{OH}) \mathrm{D}$ \\
& 2002 & U.S. & other & occupational & incidence & progression, \\
& $(118)$ & & countries & exposure & & American \\
& & & Survival
\end{tabular}

All

Epithelial

Breast

Prostate

Lung

Colon

Bladder

Melanoma

Rectal

Kidney

Pancreatic

Endometrial

Oral cavity

Ovarian

Stomach

Thyroid

Brain, CNS

Liver

Esophageal

Uterine cervix

Larynx

Pharynx

Testicular

Gallbladder

Small intestine

Vulvar

Vaginal

Hematological

NHL

Leukemia

AML (myeloma)

Hodgkin's

NHL, T-cell

Lymphoma, B-cell
(2)

\section{5,000}

180,000

169,200

107,300

56,500

53,600

41,000

31,800

30,300

30,300

28,900

23,300

21,600

20,700

17,000

16,600

13,100

13,000

8,900

8,600

7,500

7,100

5,300

3,800

1,000

$\begin{array}{lll}(2) & (2) & (28) \\ (2) & (2) & \\ (2) & (2) & \\ (2) & (2) & (28) \\ (2) & (2) & (28) \\ (2) & & (28)\end{array}$

(2)

(2)

(2)

(2)

(2)

(2)

(2)

(2)

(24)

(2)

(2)

(2)

(2)

(2)

(2)

(2)

53,900

30,800

10,000

7,000

3,200

*Did not include all three factors, stage at diagnosis, treatment, and socioeconomic status; 25(OH)D: 25-hydroxyvitamin D; AML: acute myelogenous leukemia; CLL: chronic lymphocytic leukemia; CNS: central nervous system; NHL, non-Hodgkin's lymphoma; UVB: ultraviolet-B.
(8)

(125)

(2)
(2)

(2)

$\begin{array}{ccc}(5) & (8) & (11) \\ & & (11) \\ (46) & (47) & (11)^{*} \\ (44) & (8) & (11) \\ (41) & & (11) \\ & & (11) \\ (44) & (8) & (11)^{*},(120) \\ (45) & (70) & (11)^{*} \\ (57) & (60) & \\ (60) & (8) & \\ (63) & (8) & (124) \\ (59) & & \\ (64) & (8) & (11) \\ (55) & (60) & \\ (61) & & \\ (58) & (60) & \\ (56) & (60) & \\ (60) & & \\ (60) & & \\ & & \end{array}$

(48)

(8)

(69)

(48)
(118). That order is used because the likelihood of finding effects of UVB or vitamin D is expected to increase with the annual number of cases. As seen in the table, only one observational study reported findings for cancers with fewer than 8,000 cases/y.

Evident from that Table is that 17 of the epithelial cancers have combinations of inverse correlations of incidence or progression/mortality with respect to indices of solar UVB and $25(\mathrm{OH}) \mathrm{D}$ concentration. In addition, seven of those 17 also have studies reporting significantly poorer survival rates for black Americans than white Americans. The findings are less robust for hematological cancers, with little support for protective effects against cancer incidence. However, some studies report inverse correlations between serum $25(\mathrm{OH}) \mathrm{D}$ concentration at time of diagnosis and progression or survival.

Hill's criteria for causality. Another way to assess causality is to apply A. Bradford Hill's criteria for causality in a biological system (127). The criteria appropriate for vitamin D include strength of association, consistency, temporality, biological gradient (dose-response relationship), plausibility 
Table VI. Assessing the UVB-vitamin D-cancer hypothesis by using Hill's criteria for causality in biological systems (127).

\begin{tabular}{|c|c|}
\hline Criterion & How satisfied \\
\hline Strength of association & Significantly reduced risk at $p<0.05$ for $25(\mathrm{OH}) \mathrm{D}$ concentrations for several cancers. \\
\hline Consistency & $\begin{array}{l}\text { Ecological studies in several midlatitude countries as well as occupational study in Nordic countries report } \\
\text { similar inverse correlations between solar UVB indices and cancer incidence or mortality rates. } \\
\text { Meta-analyses review several studies for cancer risk with respect to } 25(\mathrm{OH}) \mathrm{D} \text { concentration for several cancers. }\end{array}$ \\
\hline Temporality & $\begin{array}{l}\text { Prospective and NCC studies look at results later than when } 25(\mathrm{OH}) \mathrm{D} \text { concentration was measured. } \\
\text { CC studies also can satisfy the temporality criterion if the concentration is representative of the history. }\end{array}$ \\
\hline Biological gradient & $\begin{array}{l}\text { Significant inverse correlations between } 25(\mathrm{OH}) \mathrm{D} \text { concentration and cancer incidence, progression, } \\
\text { or mortality have been found for several cancers. }\end{array}$ \\
\hline Plausibility & Mechanisms have been found explaining how vitamin D reduces incidence, progression, and metastasis. \\
\hline Experiment & $\begin{array}{l}\text { Clinical trials arguably support vitamin D supplementation's role in reducing cancer risk by comparing trial } \\
\text { results with model calculations based on the } 25(\mathrm{OH}) \mathrm{D} \text { concentration-breast cancer incidence relationship. }\end{array}$ \\
\hline Analogy & $\begin{array}{l}\text { Ecological and observational studies on UVB dose or exposure since sun exposure may have other } \\
\text { cancer risk-reducing effects. } \\
\text { Observational studies of cancer risk and outcomes related to } 25(\mathrm{OH}) \mathrm{D} \text { concentration may be related } \\
\text { to solar UV exposure, not vitamin D. }\end{array}$ \\
\hline Confounding factors & Most ecological and observational studies adjust the findings for other risk-modifying factors. \\
\hline
\end{tabular}

(e.g., mechanisms), coherence with generally known facts, and experiment (e.g., clinical trial). Later authors added two more criteria: account for confounding factors and eliminate bias (128). Not all criteria need be satisfied, but the more that are, the stronger the case for causality. Hill's criteria have been applied to cancer for cancer in general (129) and breast cancer (130). Because several years have passed since those two analyses, a brief update is worthwhile. Table VI summarizes how the criteria are satisfied.

The way forward. Because clinical trials are considered the "gold standard" for determining causality, it behooves the vitamin D community to perform clinical trials that are very likely to succeed. The authors of several recent papers suggest how that can be done $(5,114)$. In addition, the results of several large-scale vitamin D clinical trials should be available in the next year or two. Although they may not have been ideally designed, they should nonetheless report reduced risk for cancer, especially among the black Americans in the Vitamin D and OmegA-3 (VITAL) trial (131).

Another factor to consider is more widespread use of CC studies in which $25(\mathrm{OH}) \mathrm{D}$ concentrations are measured near time of cancer diagnosis along with taking a recent history of supplement intake, dietary sources including meat (35), and sun exposure. Controls should be matched as well as possible, including time of blood draw.

While awaiting conclusive results on the role of UVB exposure and vitamin $\mathrm{D}$ in the risk of cancer incidence, progression, and mortality, individuals should consider sensible sun exposure and vitamin $\mathrm{D}_{3}$ supplementation to raise serum $25(\mathrm{OH}) \mathrm{D}$ concentrations to above $100-125 \mathrm{nmol} / \mathrm{l}$. That concentration was associated with significantly reduced cancer incidence in a clinical trial in Nebraska (54). Men who raise serum $25(\mathrm{OH}) \mathrm{D}$ concentrations that high may want to limit calcium supplementation to $500 \mathrm{mg} / \mathrm{d}$. As discussed in a recent paper, little reliable evidence indicates that $25(\mathrm{OH}) \mathrm{D}$ concentrations below $250 \mathrm{nmol} / 1$ are associated with adverse health outcomes, other than for prostate cancer, falls and fractures when given high-dose monthly or annual bolus vitamin D doses, and heart failure (140). In a recent study, supplementing heart failure patients with 4,000 IU/d of vitamin $\mathrm{D}_{3}$ increased the need for mechanical circulatory support implants (132). Most other studies reporting J- or U-shaped $25(\mathrm{OH}) \mathrm{D}$ concentration-health outcome relationships did not obtain a vitamin D supplementation history of the participants, and most participants with high $25(\mathrm{OH}) \mathrm{D}$ concentrations (higher than expected from solar UVB exposure) were probably taking vitamin D supplements, many starting only recently, perhaps because of osteoporosis concerns.

Many other health benefits are associated with higher $25(\mathrm{OH}) \mathrm{D}$ concentrations, including reduced risk of autoimmune diseases (133), diabetes mellitus type 2 (134), adverse pregnancy and birth outcomes (135), respiratory tract infections (136), and all-cause mortality rate (137). Whether vitamin D reduces risk of cardiovascular disease is still uncertain based on support from observational studies but not clinical trials (138). Thus, raising $25(\mathrm{OH}) \mathrm{D}$ concentrations in an effort to reduce cancer risk will yield additional benefits. The optimal $25(\mathrm{OH}) \mathrm{D}$ concentration is certainly above $75 \mathrm{nmol} / \mathrm{l}$ and more likely 100 $150 \mathrm{nmol} / 1$. Reaching those concentrations could take 1,000 $5,000 \mathrm{IU} / \mathrm{d}$ of vitamin $\mathrm{D}_{3}$ or a moderate amount of sensible sun exposure. The only way to ensure reaching the desired concentration is to have serum $25(\mathrm{OH}) \mathrm{D}$ concentration measured $(18,19)$. 


\section{Conclusion}

The UVB-vitamin D-cancer hypothesis has considerable supporting scientific evidence from a variety of study types: geographical ecological, observational, and laboratory studies of mechanisms, as well as several clinical trials. At this time, the general public and individual physicians can spend more reasonable time in the sun and use vitamin $\mathrm{D}_{3}$ to prevent and treat many cancers. Hopefully soon, the clinical evidence will be strong enough that health care systems and agencies will endorse vitamin $\mathrm{D}_{3}$ supplementation as a way to prevent and treat cancer.

\section{Acknowledgements}

The Author received funding from Bio-Tech Pharmacal, Inc. (Fayetteville, AR, U.S.A.) and in the recent past, from the Vitamin D Society (Woodstock, ON, Canada) and the Vitamin D Council (San Luis Obispo, CA, U.S.A.).

\section{References}

1 Garland CF and Garland FC: Do sunlight and vitamin d reduce the likelihood of colon cancer? Int J Epidemiol 9(3): 227-231, 1980 .

2 Moukayed M and Grant WB: Molecular link between vitamin $\mathrm{d}$ and cancer prevention. Nutrients 5(10): 3993-4021, 2013.

3 Grant WB: 25-hydroxyvitamin d and breast cancer, colorectal cancer, and colorectal adenomas: Case-control versus nested case-control studies. Anticancer Res 35(2): 1153-1160, 2015.

4 Grant WB: Roles of solar uvb and vitamin d in reducing cancer risk and increasing survival. Anticancer Res 36(3): 1357-1370, 2016.

5 Grant WB and Boucher BJ: Randomized controlled trials of vitamin $d$ and cancer incidence: A modeling study. PLoS One 12(5): e0176448, 2017.

6 Mondul AM, Weinstein SJ, Layne TM and Albanes D: Vitamin $\mathrm{d}$ and cancer risk and mortality: State of the science, gaps, and challenges. Epidemiol Rev 39(1): 28-48, 2017.

7 Moukayed $\mathrm{M}$ and Grant WB: The roles of uvb and vitamin d in reducing risk of cancer incidence and mortality: A review of the epidemiology, clinical trials, and mechanisms. Rev Endocr Metab Disord 18(2): 167-182, 2017.

8 Vaughan-Shaw PG, O'Sullivan F, Farrington SM, Theodoratou E, Campbell H, Dunlop MG and Zgaga L: The impact of vitamin $d$ pathway genetic variation and circulating 25hydroxyvitamin d on cancer outcome: Systematic review and meta-analysis. Br J Cancer 116(8): 1092-1110, 2017.

9 Bandera Merchan B, Morcillo S, Martin-Nunez G, Tinahones FJ and Macias-Gonzalez M: The role of vitamin $d$ and vdr in carcinogenesis: Through epidemiology and basic sciences. J Steroid Biochem Mol Biol 167: 203-218, 2017.

10 Bikle DD: Extraskeletal actions of vitamin d. Ann NY Acad Sci 1376(1): 29-52, 2016.

11 Grant WB and Peiris AN: Differences in vitamin d status may account for unexplained disparities in cancer survival rates between african and white americans. Dermatoendocrinol 4(2): 85-94, 2012.
12 Fleischer AB Jr. and Fleischer SE: Solar radiation and the incidence and mortality of leading invasive cancers in the united states. Dermatoendocrinol 8(1): e1162366, 2016.

13 Grant WB: An estimate of premature cancer mortality in the u.S. Due to inadequate doses of solar ultraviolet-b radiation. Cancer 94(6): 1867-1875, 2002.

14 Zamoiski RD, Freedman DM, Linet MS, Kitahara CM, Liu W and Cahoon EK: Prospective study of ultraviolet radiation exposure and risk of breast cancer in the united states. Environ Res 151: 419-427, 2016.

15 Grant WB: Does solar ultraviolet irradiation affect cancer mortality rates in china? Asian Pac J Cancer Prev 8(2): 236242, 2007.

16 Grant WB and Garland CF: The association of solar ultraviolet b (uvb) with reducing risk of cancer: Multifactorial ecologic analysis of geographic variation in age-adjusted cancer mortality rates. Anticancer Res 26(4A): 2687-2699, 2006.

17 Rebel H, der Spek CD, Salvatori D, van Leeuwen JP, RobanusMaandag EC and de Gruijl FR: Uv exposure inhibits intestinal tumor growth and progression to malignancy in intestinespecific apc mutant mice kept on low vitamin d diet. Int $\mathrm{J}$ Cancer 136(2): 271-277, 2015.

18 Garland CF, French CB, Baggerly LL and Heaney RP: Vitamin $\mathrm{d}$ supplement doses and serum 25-hydroxyvitamin $\mathrm{d}$ in the range associated with cancer prevention. Anticancer Res 31(2): 607611,2011

19 Ekwaru JP, Zwicker JD, Holick MF, Giovannucci E and Veugelers: The importance of body weight for the dose response relationship of oral vitamin D supplementation and serum 25-hydroxyvitamin D in healthy volunteers. PLoS One 9(11): e111265, 2014

20 National Institute of Health: Atlas of cancer mortality in the united states, 1950-1994 (1999). Available at http://www3.cancer.gov/ atlasplus/new.html. Last accessed on November 8, 2008.

21 Boscoe FP and Schymura MJ: Solar ultraviolet-b exposure and cancer incidence and mortality in the united states, 1993-2002. BMC Cancer 6: 264, 2006

22 Lin SW, Wheeler DC, Park Y, Cahoon EK, Hollenbeck AR, Freedman DM and Abnet CC: Prospective study of ultraviolet radiation exposure and risk of cancer in the united states. Int $\mathbf{J}$ Cancer 131(6): E1015-1023, 2012.

23 Zamoiski RD, Cahoon EK, Freedman DM, Linet MS and Kitahara CM: Prospective study of ultraviolet radiation exposure and thyroid cancer risk in the united states. Cancer Epidemiol Biomarkers Prev 26(5): 684-691, 2017.

24 VoPham T, Bertrand KA, Yuan JM, Tamimi RM, Hart JE and Laden F: Ambient ultraviolet radiation exposure and hepatocellular carcinoma incidence in the united states. Environ Health 16(1): 89, 2017.

25 Grant WB: Re: Prospective study of ultraviolet radiation exposure and risk of breast cancer in the united states. Environ Res 152: 517-518, 2017.

26 Drincic AT, Armas LA, Van Diest EE and Heaney RP: Volumetric dilution, rather than sequestration best explains the low vitamin d status of obesity. Obesity (Silver Spring) 20(7): 1444-1448, 2012.

27 Pukkala E, Martinsen JI, Lynge E, Gunnarsdottir HK, Sparen P, Tryggvadottir L, Weiderpass E and Kjaerheim K: Occupation and cancer - follow-up of 15 million people in five nordic countries. Acta Oncol 48(5): 646-790, 2009. 
28 Grant WB: Role of solar uvb irradiance and smoking in cancer as inferred from cancer incidence rates by occupation in nordic countries. Dermatoendocrinol 4(2): 203-211, 2012.

29 Chang YM, Barrett JH, Bishop DT, Armstrong BK, Bataille V, Bergman W, Berwick M, Bracci PM, Elwood JM, Ernstoff MS, Gallagher RP, Green AC, Gruis NA, Holly EA, Ingvar C, Kanetsky PA, Karagas MR, Lee TK, Le Marchand L, Mackie RM, Olsson H, Osterlind A, Rebbeck TR, Sasieni P, Siskind V, Swerdlow AJ, Titus-Ernstoff L, Zens MS and Newton-Bishop JA: Sun exposure and melanoma risk at different latitudes: A pooled analysis of 5700 cases and 7216 controls. Int J Epidemiol 38(3): 814-830, 2009.

30 Grant WB: Effect of interval between serum draw and followup period on relative risk of cancer incidence with respect to 25-hydroxyvitamin d level: Implications for meta-analyses and setting vitamin d guidelines. Dermatoendocrinol 3(3): 199-204, 2011.

31 Grant WB: Effect of follow-up time on the relation between prediagnostic serum 25-hydroxyvitamin $d$ and all-cause mortality rate. Dermatoendocrinol 4(2): 198-202, 2012.

32 Jacobs ET, Thomson CA, Flatt SW, Newman VA, Rock CL and Pierce JP: Correlates of 25-hydroxyvitamin $\mathrm{d}$ and breast cancer stage in the women's healthy eating and living study. Nutr Cancer 65(2): 188-194, 2013.

33 Shi L, Nechuta S, Gao YT, Zheng Y, Dorjgochoo T, Wu J, Cai Q, Zheng W, Lu W and Shu XO: Correlates of 25hydroxyvitamin $d$ among chinese breast cancer patients. PLoS One 9(1): e86467, 2014.

34 Oh EY, Ansell C, Nawaz H, Yang CH, Wood PA and Hrushesky WJ: Global breast cancer seasonality. Breast Cancer Res Treat 123(1): 233-243, 2010.

35 Crowe FL, Steur M, Allen NE, Appleby PN, Travis RC and Key TJ: Plasma concentrations of 25-hydroxyvitamin d in meat eaters, fish eaters, vegetarians and vegans: Results from the epic-oxford study. Public Health Nutr 14(2): 340-346, 2011.

36 Norat T, Bingham S, Ferrari P, Slimani N, Jenab M, Mazuir M, Overvad K, Olsen A, Tjonneland A, Clavel F, Boutron-Ruault MC, Kesse E, Boeing H, Bergmann MM, Nieters A, Linseisen J, Trichopoulou A, Trichopoulos D, Tountas Y, Berrino F, Palli D, Panico S, Tumino R, Vineis P, Bueno-de-Mesquita HB, Peeters PH, Engeset D, Lund E, Skeie G, Ardanaz E, Gonzalez C, Navarro C, Quiros JR, Sanchez MJ, Berglund G, Mattisson I, Hallmans G, Palmqvist R, Day NE, Khaw KT, Key TJ, San Joaquin M, Hemon B, Saracci R, Kaaks R and Riboli E: Meat, fish, and colorectal cancer risk: The european prospective investigation into cancer and nutrition. J Natl Cancer Inst 97(12): 906-916, 2005.

37 Aune D, De Stefani E, Ronco A, Boffetta P, Deneo-Pellegrini $\mathrm{H}$, Acosta $\mathrm{G}$ and Mendilaharsu M: Meat consumption and cancer risk: A case-control study in uruguay. Asian Pac J Cancer Prev 10(3): 429-436, 2009.

38 Aune D, De Stefani E, Ronco AL, Boffetta P, Deneo-Pellegrini $\mathrm{H}$, Acosta G and Mendilaharsu M: Egg consumption and the risk of cancer: A multisite case-control study in uruguay. Asian Pac J Cancer Prev 10(5): 869-876, 2009.

39 Mourouti N, Papavagelis C, Plytzanopoulou P, Kontogianni M, Vassilakou T, Malamos N, Linos A and Panagiotakos D: Dietary patterns and breast cancer: a case-control study in women. Eur J Nutr 54(4): 609-617, 2015.
40 Yin L, Ordonez-Mena JM, Chen T, Schottker B, Arndt V and Brenner H: Circulating 25-hydroxyvitamin d serum concentration and total cancer incidence and mortality: A systematic review and meta-analysis. Prev Med 57(6): 753-764, 2013

41 Zhao Y, Chen C, Pan W, Gao M, He W, Mao R, Lin T and Huang J: Comparative efficacy of vitamin $\mathrm{d}$ status in reducing the risk of bladder cancer: A systematic review and network meta-analysis. Nutrition 32(5): 515-523, 2016.

42 Yin L, Grandi N, Raum E, Haug U, Arndt V and Brenner H: Meta-analysis: Serum vitamin d and breast cancer risk. Eur J Cancer 46(12): 2196-2205, 2010.

43 Kim Y and Je Y: Vitamin d intake, blood 25(oh)d levels, and breast cancer risk or mortality: A meta-analysis. Br J Cancer 110(11): 2772-2784, 2014.

44 Garland CF and Gorham ED: Dose-response of serum 25hydroxyvitamin $\mathrm{d}$ in association with risk of colorectal cancer: A meta-analysis. J Steroid Biochem Mol Biol 168: 1-8, 2017.

45 Lin G, Ning L, Gu D, Li S, Yu Z, Long Q, Hou LN and Tan WL: Examining the association of circulating 25hydroxyvitamin d with kidney cancer risk: A meta-analysis. Int J Clin Exp Med 8(11): 20499-20507, 2015.

46 Chen GC, Zhang ZL, Wan Z, Wang L, Weber P, Eggersdorfer M, Qin LQ and Zhang W: Circulating 25-hydroxyvitamin d and risk of lung cancer: A dose-response meta-analysis. Cancer Causes Control 26: 1719-1728, 2015.

47 Liu D, Peng H, Sun Q, Zhao Z, Yu X, Ge S, Wang H, Fang H, Gao Q, Liu J, Wu L, Song M and Wang Y: The indirect efficacy comparison of DNA methylation in sputum for early screening and auxiliary detection of lung cancer: A meta-analysis. Int J Environ Res Public Health 14(7): pii: E679, 2017.

48 Lu D, Chen J and Jin J: Vitamin d status and risk of nonhodgkin lymphoma: A meta-analysis. Cancer Causes Control 25(11): 1553-1563, 2014.

49 Yin L, Grandi N, Raum E, Haug U, Arndt V and Brenner H: Meta-analysis: Circulating vitamin $\mathrm{d}$ and ovarian cancer risk. Gynecol Oncol 121(2): 369-375, 2011.

50 Liu SL, Zhao YP, Dai MH, You L, Wen Z and Xu JW: Vitamin $\mathrm{d}$ status and the risk of pancreatic cancer: A meta-analysis. Chin Med J (Engl) 126(17): 3356-3359, 2013.

51 Zhang X, Huang X-Z, Chen W-J, Wu J, Chen Y, Wu C-C and Wang ZN: Plasma 25-hydroxyvitamin d levels, vitamin d intake, and pancreatic risk or mortality: A meta-analysis. Oncotarget 8(38): 64395-64406, 2017.

$52 \mathrm{Xu}$ Y, Shao X, Yao Y, Xu L, Chang L, Jiang Z and Lin Z: Positive association between circulating 25-hydroxyvitamin d levels and prostate cancer risk: New findings from an updated meta-analysis. J Cancer Res Clin Oncol 140(9): 1465-1477, 2014.

53 Khayatzadeh S, Feizi A, Saneei P and Esmaillzadeh A: Vitamin $\mathrm{d}$ intake, serum vitamin d levels, and risk of gastric cancer: A systematic review and meta-analysis. J Res Med Sci 20(8): 790796, 2015.

54 Lappe J, Watson P, Travers-Gustafson D, Recker R, Garland C, Gorham E, Baggerly K and McDonnell SL: Effect of vitamin d and calcium supplementation on cancer incidence in older women: A randomized clinical trial. JAMA 317(12): 1234-1243, 2017.

55 Zigmont V, Garrett A, Peng J, Seweryn M, Rempala GA, Harris R, Holloman C, Gundersen TE, Ahlbom A, Feychting M, Johannesen TB, Grimsrud TK and Schwartzbaum J: Association between prediagnostic serum 25-hydroxyvitamin d concentration and glioma. Nutr Cancer 67(7): 1120-1130, 2015. 
56 Hosono S, Matsuo K, Kajiyama H, Hirose K, Suzuki T, Kawase T, Kidokoro K, Nakanishi T, Hamajima N, Kikkawa F, Tajima $\mathrm{K}$ and Tanaka $\mathrm{H}$ : Association between dietary calcium and vitamin $\mathrm{d}$ intake and cervical carcinogenesis among japanese women. Eur J Clin Nutr 64(4): 400-409, 2010.

57 Liu JJ, Bertrand KA, Karageorgi S, Giovannucci E, Hankinson SE, Rosner B, Maxwell L, Rodriguez G and De Vivo I: Prospective analysis of vitamin $\mathrm{d}$ and endometrial cancer risk. Ann Oncol 24(3): 687-692, 2013.

58 Yang J, Wang H, Ji A, Ma L, Wang J, Lian C, Wei Z and Wang L: Vitamin d signaling pathways confer the susceptibility of esophageal squamous cell carcinoma in a northern chinese population. Nutr Cancer 69(4): 593-600, 2017.

59 Vyas N, Companioni RC, Tiba M, Alkhawam H, Catalano C, Sogomonian R, Baum J and Walfish A: Association between serum vitamin d levels and gastric cancer: A retrospective chart analysis. World J Gastrointest Oncol 8(9): 688-694, 2016.

60 Fanidi A, Muller DC, Midttun O, Ueland PM, Vollset SE, Relton C, Vineis P, Weiderpass E, Skeie G, Brustad M, Palli D, Tumino R, Grioni S, Sacerdote C, Bueno-de-Mesquita HB, Peeters PH, Boutron-Ruault MC, Kvaskoff M, Cadeau C, Huerta JM, Sanchez MJ, Agudo A, Lasheras C, Quiros JR, Chamosa S, Riboli E, Travis RC, Ward H, Murphy N, Khaw KT, Trichopoulou A, Lagiou P, Papatesta EM, Boeing H, Kuehn T, Katzke V, Steffen A, Johansson A, Brennan P and Johansson M: Circulating vitamin $d$ in relation to cancer incidence and survival of the head and neck and oesophagus in the epic cohort. Sci Rep 6: 36017, 2016.

61 Fedirko V, Duarte-Salles T, Bamia C, Trichopoulou A, Aleksandrova K, Trichopoulos D, Trepo E, Tjonneland A, Olsen A, Overvad K, Boutron-Ruault MC, Clavel-Chapelon F, Kvaskoff M, Kuhn T, Lukanova A, Boeing H, Buijsse B, Klinaki E, Tsimakidi C, Naccarati A, Tagliabue G, Panico S, Tumino R, Palli D, Bueno-de-Mesquita HB, Siersema PD, Peters PH, Lund E, Brustad M, Olsen KS, Weiderpass E, Zamora-Ros R, Sanchez MJ, Ardanaz E, Amiano P, Navarro C, Quiros JR, Werner M, Sund M, Lindkvist B, Malm J, Travis RC, Khaw KT, Stepien M, Scalbert A, Romieu I, Lagiou P, Riboli E and Jenab M: Prediagnostic circulating vitamin $d$ levels and risk of hepatocellular carcinoma in european populations: A nested case-control study. Hepatology 60(4): 1222-1230, 2014.

62 Luczynska A, Kaaks R, Rohrmann S, Becker S, Linseisen J, Buijsse B, Overvad K, Trichopoulou A, Valanou E, Barmpitsioti A, Masala G, Agnoli C, Tumino R, Panico S, Bueno-deMesquita HB, van Duijnhoven FJ, Peeters PH, Vermeulen R, Weiderpass E, Brustad M, Skeie G, Gonzalez CA, Jakszyn P, Quiros JR, Sanchez MJ, Huerta JM, Ardanaz E, Melin B, Johansson AS, Almquist M, Malm J, Khaw KT, Wareham N, Travis RC, Fedirko V, Romieu I, Jenab M, Gallo V, Riboli E, Vineis $\mathrm{P}$ and Nieters A: Plasma 25-hydroxyvitamin $\mathrm{d}$ concentration and lymphoma risk: Results of the european prospective investigation into cancer and nutrition. Am J Clin Nutr 98(3): 827-838, 2013

63 Granato T, Manganaro L, Petri L, Porpora MG, Viggiani V, Angeloni A and Anastasi E: Low 25-oh vitamin d levels at time of diagnosis and recurrence of ovarian cancer. Tumour Biol 37(2): 2177-2181, 2016.

64 Roskies M, Dolev Y, Caglar D, Hier MP, Mlynarek A, Majdan A and Payne RJ: Vitamin d deficiency as a potentially modifiable risk factor for thyroid cancer. J Otolaryngol Head Neck Surg 41(3): 160-163, 2012.

65 Salehin D, Haugk C, Thill M, Cordes T, Hornung D, AbuHechle A, Hemmerlein B and Friedrich M: Serum 25hydroxyvitamin d levels in patients with vulvar cancer. Anticancer Res 32(1): 265-270, 2012.

$66 \mathrm{Hu} \mathrm{K}$, Callen DF, Li J and Zheng H: Circulating vitamin d and overall survival in breast cancer patients: A dose-response metaanalysis of cohort studies. Integr Cancer Ther 1: 15347354 17712007, 2017.

67 Mohr SB, Gorham ED, Kim J, Hofflich H, Cuomo RE and Garland CF: Could vitamin d sufficiency improve the survival of colorectal cancer patients? J Steroid Biochem Mol Biol 148: 239-244, 2015.

68 Li M, Chen P, Li J, Chu R, Xie D and Wang H: Review: The impacts of circulating 25-hydroxyvitamin d levels on cancer patient outcomes: A systematic review and meta-analysis. J Clin Endocrinol Metab 99(7): 2327-2336, 2014.

69 Wang W, Li G, He X, Gao J, Wang R, Wang Y and Zhao W: Serum 25-hydroxyvitamin $\mathrm{d}$ levels and prognosis in hematological malignancies: A systematic review and metaanalysis. Cell Physiol Biochem 35(5): 1999-2005, 2015.

70 Yuan C, Qian ZR, Babic A, Morales-Oyarvide V, Rubinson DA, Kraft P, Ng K, Bao Y, Giovannucci EL, Ogino S, Stampfer MJ, Gaziano JM, Sesso HD, Buring JE, Cochrane BB, Chlebowski RT, Snetselaar LG, Manson JE, Fuchs CS and Wolpin BM: Prediagnostic plasma 25-hydroxyvitamin d and pancreatic cancer survival. J Clin Oncol 34(24): 28992905, 2016.

71 Peiris AN, Bailey BA and Manning T: Relationship of vitamin $\mathrm{d}$ monitoring and status to bladder cancer survival in veterans. South Med J 106(2): 126-130, 2013.

72 Muller DC, Scelo G, Zaridze D, Janout V, Holcatova I, Navratilova M, Mates D, Midttun O, Ueland PM, Brennan P and Johansson M: Circulating 25-hydroxyvitamin d3 and survival after diagnosis with kidney cancer. Cancer Epidemiol Biomarkers Prev 24(8): 1277-1281, 2015.

73 Finkelmeier F, Kronenberger B, Koberle V, Bojunga J, Zeuzem S, Trojan J, Piiper A and Waidmann O: Commentary: Vitamin d deficiency and liver cancer - cause, effect or myth? Authors' reply. Aliment Pharmacol Ther 39(12): 1429-1430, 2014.

74 Kelly JL, Salles G, Goldman B, Fisher RI, Brice P, Press O, Casasnovas O, Maloney DG, Soubeyran P, Rimsza L, Haioun C, Xerri L, LeBlanc M, Tilly H and Friedberg JW: Low serum vitamin $d$ levels are associated with inferior survival in follicular lymphoma: A prospective evaluation in swog and lysa studies. J Clin Oncol 33(13): 1482-1490, 2015.

75 Saiag P, Aegerter P, Vitoux D, Lebbe C, Wolkenstein P, Dupin $\mathrm{N}$, Descamps V, Aractingi S, Funck-Brentano E, Autier P, Dragomir $M$ and Boniol $M$ : Prognostic value of 25hydroxyvitamin $\mathrm{d} 3$ levels at diagnosis and during follow-up in melanoma patients. J Natl Cancer Inst 107(12): djv264, 2015.

76 Webb PM, de Fazio A, Protani MM, Ibiebele TI, Nagle CM, Brand AH, Blomfield PI, Grant P, Perrin LC and Neale RE: Circulating 25-hydroxyvitamin $\mathrm{d}$ and survival in women with ovarian cancer. Am J Clin Nutr 102(1): 109-114, 2015.

77 Mondul AM, Weinstein SJ, Moy KA, Mannisto S and Albanes D: Circulating 25-hydroxyvitamin $\mathrm{d}$ and prostate cancer survival. Cancer Epidemiol Biomarkers Prev 25(4): 665-669, 2016. 
78 Meyer HE, Stoer NC, Samuelsen SO, Blomhoff R, Robsahm TE, Brustad M, Giovannucci EL and Bjorge T: Long term association between serum 25-hydroxyvitamin d and mortality in a cohort of 4379 men. PLoS One 11(3): e0151441, 2016.

79 Ren C, Qiu MZ, Wang DS, Luo HY, Zhang DS, Wang ZQ, Wang FH, Li YH, Zhou ZW and Xu RH: Prognostic effects of 25-hydroxyvitamin d levels in gastric cancer. J Transl Med 10: 16, 2012.

80 Ahn HY, Chung YJ, Park KY and Cho BY: Serum 25hydroxyvitamin d level does not affect the aggressiveness and prognosis of papillary thyroid cancer. Thyroid 26(3): 429-433, 2016.

81 Helzlsouer KJ and Committee VS: Overview of the cohort consortium vitamin d pooling project of rarer cancers. Am J Epidemiol 172(1): 4-9, 2010.

82 Toriola AT, Surcel HM, Calypse A, Grankvist K, Luostarinen T, Lukanova A, Pukkala E and Lehtinen M: Independent and joint effects of serum 25-hydroxyvitamin $\mathrm{d}$ and calcium on ovarian cancer risk: A prospective nested case-control study. Eur J Cancer 46(15): 2799-2805, 2010.

83 Albanes D, Heinonen OP, Taylor PR, Virtamo J, Edwards BK, Rautalahti M, Hartman AM, Palmgren J, Freedman LS, Haapakoski J, Barrett MJ, Pietinen P, Malila N, Tala E, Liippo K, Salomaa ER, Tangrea JA, Teppo L, Askin FB, Taskinen E, Erozan Y, Greenwald P and Huttunen JK: Alpha-tocopherol and beta-carotene supplements and lung cancer incidence in the alpha-tocopherol, beta-carotene cancer prevention study: Effects of base-line characteristics and study compliance. J Natl Cancer Inst 88(21): 1560-1570, 1996.

84 Tangrea J, Helzlsouer K, Pietinen P, Taylor P, Hollis B, Virtamo $\mathrm{J}$ and Albanes D: Serum levels of vitamin d metabolites and the subsequent risk of colon and rectal cancer in finnish men. Cancer Causes Control 8(4): 615-625, 1997.

85 Weinstein SJ, Yu K, Horst RL, Ashby J, Virtamo J and Albanes D: Serum 25-hydroxyvitamin d and risks of colon and rectal cancer in finnish men. Am J Epidemiol 173(5): 499-508, 2011.

86 Stolzenberg-Solomon RZ, Vieth R, Azad A, Pietinen P, Taylor PR, Virtamo J and Albanes D: A prospective nested case-control study of vitamin d status and pancreatic cancer risk in male smokers. Cancer Res 66(20): 10213-10219, 2006.

87 Stolzenberg-Solomon RZ, Hayes RB, Horst RL, Anderson KE, Hollis BW and Silverman DT: Serum vitamin d and risk of pancreatic cancer in the prostate, lung, colorectal, and ovarian screening trial. Cancer Res 69(4): 1439-1447, 2009.

88 Kroll MH, Bi C, Garber CC, Kaufman HW, Liu D, CastonBalderrama A, Zhang K, Clarke N, Xie M, Reitz RE, Suffin SC and Holick MF: Temporal relationship between vitamin d status and parathyroid hormone in the united states. PLoS One 10(3): e0118108, 2015.

89 Theodoratou E, Tzoulaki I, Zgaga L and Ioannidis JP: Vitamin $\mathrm{d}$ and multiple health outcomes: Umbrella review of systematic reviews and meta-analyses of observational studies and randomised trials. BMJ 348: g2035, 2014.

90 Altieri B, Grant WB, Della Casa S, Orio F, Pontecorvi A, Colao A, Sarno G and Muscogiuri G: Vitamin d and pancreas: The role of sunshine vitamin in the pathogenesis of diabetes mellitus and pancreatic cancer. Crit Rev Food Sci Nutr 57(16): 34723488, 2017.

91 Chen W, Dawsey SM, Qiao YL, Mark SD, Dong ZW, Taylor PR, Zhao P and Abnet CC: Prospective study of serum 25(oh)- vitamin d concentration and risk of oesophageal and gastric cancers. Br J Cancer 97(1): 123-128, 2007.

92 Zheng S, Vuitton L, Sheyhidin I, Vuitton DA, Zhang Y and Lu $\mathrm{X}$ : Northwestern China: a place to learn more on oesophageal cancer. Part one: behavioural and environmental risk factors. Eur J Gastroenterol Hepatol 22(8): 917-925, 2010.

93 Nair-Shalliker V, Smith DP, Egger S, Hughes AM, Kaldor JM, Clements M, Kricker A and Armstrong BK: Sun exposure may increase risk of prostate cancer in the high UV environment of New South Wales, Australia: a case-control study. Int J Cancer 131(5): E726-E732, 2012.

94 Tuohimaa P, Tenkanen L, Ahonen M, Lumme S, Jellum E, Hallmans G, Stattin P, Harvei S, Hakulinen T, Luostarinen T, Dillner J, Lehtinen M and Hakama M: Both high and low levels of blood vitamin $\mathrm{d}$ are associated with a higher prostate cancer risk: A longitudinal, nested case-control study in the nordic countries. Int J Cancer 108(1): 104-108, 2004.

95 Tseng M, Breslow RA, Graubard BI and Ziegler RG: Dairy, calcium, and vitamin $d$ intakes and prostate cancer risk in the national health and nutrition examination epidemiologic followup study cohort. Am J Clin Nutr 81(5): 1147-1154, 2005.

96 Rowland GW, Schwartz GG, John EM and Ingles SA: Calcium intake and prostate cancer among african americans: Effect modification by vitamin $\mathrm{d}$ receptor calcium absorption genotype. J Bone Miner Res 27(1): 187-194, 2012.

97 Rai V, Abdo J, Agrawal S and Agrawal DK: Vitamin d receptor polymorphism and cancer: An update. Anticancer Res 37(8): 3991-4003, 2017.

98 Abboud M, Rybchyn MS, Rizk R, Fraser DR and Mason RS: Sunlight exposure is just one of the factors which influence vitamin d status. Photochem Photobiol Sci 16(3): 302-313, 2017.

99 Theodoratou E, Palmer T, Zgaga L, Farrington SM, McKeigue P, Din FV, Tenesa A, Davey-Smith G, Dunlop MG and Campbell H: Instrumental variable estimation of the causal effect of plasma 25-hydroxy-vitamin d on colorectal cancer risk: A mendelian randomization analysis. PLoS One 7(6): e37662, 2012.

100 Bull CJ, Yarmolinsky J and Wade KH: Commentary: Mendelian randomization analysis identifies circulating vitamin $\mathrm{d}$ as a causal risk factor for ovarian cancer. Int J Epidemiol 45(5): 1631-1633, 2016.

101 Ong JS, Cuellar-Partida G, Lu Y, Fasching PA, Hein A, Burghaus S, Beckmann MW, Lambrechts D, Van Nieuwenhuysen E, Vergote I, Vanderstichele A, Anne Doherty J, Anne Rossing M, Chang-Claude J, Eilber U, Rudolph A, Wang-Gohrke S, Goodman MT, Bogdanova N, Dork T, Durst M, Hillemanns P, Runnebaum IB, Antonenkova N, Butzow R, Leminen A, Nevanlinna H, Pelttari LM, Edwards RP, Kelley JL, Modugno F, Moysich KB, Ness RB, Cannioto R, Hogdall E, Hogdall CK, Jensen A, Giles GG, Bruinsma F, Kjaer SK, Hildebrandt MA, Liang D, Lu KH, Wu X, Bisogna M, Dao F, Levine DA, Cramer DW, Terry KL, Tworoger SS, Stampfer M, Missmer S, Bjorge L, Salvesen HB, Kopperud RK, Bischof K, Aben KK, Kiemeney LA, Massuger LF, Brooks-Wilson A, Olson SH, McGuire V, Rothstein JH, Sieh W, Whittemore AS, Cook LS, Le ND, Gilks CB, Gronwald J, Jakubowska A, Lubinski J, Kluz T, Song H, Tyrer JP, Wentzensen N, Brinton L, Trabert B, Lissowska J, McLaughlin JR, Narod SA, Phelan C, Anton-Culver H, Ziogas A, Eccles D, Campbell I, Gayther SA, 
Gentry-Maharaj A, Menon U, Ramus SJ, Wu AH, DansonkaMieszkowska A, Kupryjanczyk J, Timorek A, Szafron L, Cunningham JM, Fridley BL, Winham SJ, Bandera EV, Poole EM, Morgan TK, Risch HA, Goode EL, Schildkraut JM, Pearce CL, Berchuck A, Pharoah PD, Chenevix-Trench G, Gharahkhani P, Neale RE, Webb PM and MacGregor S: Association of vitamin d levels and risk of ovarian cancer: A mendelian randomization study. Int J Epidemiol 45(5): 1619-1630, 2016.

102 Afzal S, Brondum-Jacobsen P, Bojesen SE and Nordestgaard BG: Genetically low vitamin $\mathrm{d}$ concentrations and increased mortality: Mendelian randomisation analysis in three large cohorts. BMJ 349: g6330, 2014.

103 Garland CF, Gorham ED, Mohr SB and Garland FC: Vitamin $\mathrm{d}$ for cancer prevention: Global perspective. Ann Epidemiol 19(7): 468-483, 2009.

104 Haussler MR, Whitfield GK, Kaneko I, Haussler CA, Hsieh D, Hsieh JC and Jurutka PW: Molecular mechanisms of vitamin d action. Calcif Tissue Int 92(2): 77-98, 2013.

105 Feldman D, Krishnan AV, Swami S, Giovannucci E and Feldman BJ: The role of vitamin $d$ in reducing cancer risk and progression. Nat Rev Cancer 14(5): 342-357, 2014.

106 Gotzsche PC: Deadly medicines and organized crime; how big pharma has corrupted healthcare. London, New York, Radcliffe Publishing, 2013.

107 Rejnmark L, Bislev LS, Cashman KD, Eiriksdottir G, Gaksch M, Grubler M, Grimnes G, Gudnason V, Lips P, Pilz S, van Schoor NM, Kiely M and Jorde R: Non-skeletal health effects of vitamin d supplementation: A systematic review on findings from meta-analyses summarizing trial data. PLoS One 12(7): e0180512, 2017.

108 Lappe JM, Travers-Gustafson D, Davies KM, Recker RR and Heaney RP: Vitamin $d$ and calcium supplementation reduces cancer risk: Results of a randomized trial. Am J Clin Nutr 85(6): 1586-1591, 2007.

109 Bolland MJ, Grey A, Gamble GD and Reid IR: Calcium and vitamin d supplements and health outcomes: A reanalysis of the women's health initiative (whi) limited-access data set. Am J Clin Nutr 94(4): 1144-1149, 2011.

110 Marshall DT, Savage SJ, Garrett-Mayer E, Keane TE, Hollis BW, Horst RL, Ambrose LH, Kindy MS and Gattoni-Celli S: Vitamin d3 supplementation at 4000 international units per day for one year results in a decrease of positive cores at repeat biopsy in subjects with low-risk prostate cancer under active surveillance. J Clin Endocrinol Metab 97(7): 23152324, 2012.

111 Hollis BW, Marshall DT, Savage SJ, Garrett-Mayer E, Kindy MS and Gattoni-Celli S: Vitamin d3 supplementation, low-risk prostate cancer, and health disparities. J Steroid Biochem Mol Biol 136: 233-237, 2013.

$112 \mathrm{Ng} \mathrm{K}$, Nimeiri HS, McCleary NJ, Abrams TA, Yurgelun MB, Cleary JM, Rubinson DA, Schrag D, Allen JN, Zuckerman DS, Miksad RA, Chan E, Constantine M, Weskstein D, Faggen M, Thomas CA, Kournioti CS, Mackintosh C, Zheng H, and Fuchs CS. SUNSHINE: Randomized Double-Blind Phase II Trial of Vitamin D Supplementation in Patients with Previously Untreated Metastatic Colorectal Cancer. ASCO Annual Meeting. J Clin Oncol 35 (suppl): abstr 3506, 2017. http:// abstracts.asco.org/199/AbstView_199_183562.html

113 Heaney RP: Guidelines for optimizing design and analysis of clinical studies of nutrient effects. Nutr Rev 72(1): 48-54, 2014.
114 Grant WB, Boucher BJ, Bhattoa HP and Lahore H: Why vitamin D clinical trials should be based on 25-hydroxyvitamin D concentrations. J Steroid Biochem Mol Biol, 2017. doi: 10.1016/j.jsbmb.2017.08.009. [Epub ahead of print]

115 Ginde AA, Liu MC and Camargo CA Jr.: Demographic differences and trends of vitamin d insufficiency in the us population, 1988-2004. Arch Intern Med 169(6): 626-632, 2009.

116 Powe CE, Evans MK, Wenger J, Zonderman AB, Berg AH, Nalls M, Tamez H, Zhang D, Bhan I, Karumanchi SA, Powe NR and Thadhani R: Vitamin d-binding protein and vitamin $\mathrm{d}$ status of black americans and white americans. N Engl J Med 369(21): 1991-2000, 2013.

117 Andersen SW, Shu XO, Cai Q, Khankari NK, Steinwandel MD, Jurutka PW, Blot WJ and Zheng W: Total and free circulating vitamin $\mathrm{d}$ and vitamin d-binding protein in relation to colorectal cancer risk in a prospective study of african americans. Cancer Epidemiol Biomarkers Prev 26(8): 1242-1247, 2017.

118 Jemal A, Thomas A, Murray T and Thun M: Cancer statistics, 2002. CA Cancer J Clin 52(1): 23-47, 2002.

119 Tran B, Whiteman DC, Webb PM, Fritschi L, Fawcett J, Risch HA, Lucas R, Pandeya N, Schulte A and Neale RE: Association between ultraviolet radiation, skin sun sensitivity and risk of pancreatic cancer. Cancer Epidemiol 37(6): 886892, 2013.

120 Long B, Liu FW and Bristow RE: Disparities in uterine cancer epidemiology, treatment, and survival among african americans in the united states. Gynecol Oncol 130(3): 652659, 2013.

121 Tran B, Jordan SJ, Lucas R, Webb PM and Neale R: Association between ambient ultraviolet radiation and risk of epithelial ovarian cancer. Cancer Prev Res (Phila) 5(11): 13301336, 2012.

122 Prescott J, Bertrand KA, Poole EM, Rosner BA and Tworoger SS: Surrogates of long-term vitamin d exposure and ovarian cancer risk in two prospective cohort studies. Cancers (Basel) 5(4): 1577-1600, 2013.

123 Tran B, Lucas R, Kimlin M, Whiteman D and Neale R: Association between ambient ultraviolet radiation and risk of esophageal cancer. Am J Gastroenterol 107(12): 1803-1813, 2012.

124 Sheppard CS, El-Zein M, Ramanakumar AV, Ferenczy A and Franco EL: Assessment of mediators of racial disparities in cervical cancer survival in the united states. Int $\mathrm{J}$ Cancer 138(11): 2622-2630, 2016.

125 Hughes AM, Armstrong BK, Vajdic CM, Turner J, Grulich AE, Fritschi L, Milliken S, Kaldor J, Benke G and Kricker A: Sun exposure may protect against non-hodgkin lymphoma: A casecontrol study. Int J Cancer 112(5): 865-871, 2004.

126 Karami S, Brennan P, Hung RJ, Boffetta P, Toro J, Wilson RT, Zaridze D, Navratilova M, Chatterjee N, Mates D, Janout V, Kollarova H, Bencko V, Szeszenia-Dabrowska N, Holcatova I, Moukeria A, Welch R, Chanock S, Rothman N, Chow WH and Moore LE: Vitamin d receptor polymorphisms and renal cancer risk in central and eastern europe. J Toxicol Environ Health A 71(6): 367-372, 2008.

127 Hill AB: The environment and disease: Association or causation? Proc R Soc Med 58: 295-300, 1965.

128 Potischman N and Weed DL: Causal criteria in nutritional epidemiology. Am J Clin Nutr 69(6): 1309S-1314S, 1999. 
129 Grant WB: How strong is the evidence that solar ultraviolet $b$ and vitamin $d$ reduce the risk of cancer?: An examination using hill's criteria for causality. Dermatoendocrinol 1(1): 17-24, 2009.

130 Mohr SB, Gorham ED, Alcaraz JE, Kane CI, Macera CA, Parsons JK, Wingard DL and Garland CF: Does the evidence for an inverse relationship between serum vitamin $\mathrm{d}$ status and breast cancer risk satisfy the hill criteria? Dermatoendocrinol 4(2): 152-157, 2012.

131 Manson JE, Bassuk SS, Lee IM, Cook NR, Albert MA, Gordon D, Zaharris E, Macfadyen JG, Danielson E, Lin J, Zhang SM and Buring JE: The vitamin $d$ and omega-3 trial (vital): Rationale and design of a large randomized controlled trial of vitamin $d$ and marine omega- 3 fatty acid supplements for the primary prevention of cancer and cardiovascular disease. Contemp Clin Trials 33(1): 159-171, 2012.

132 Zittermann A, Ernst JB, Prokop S, Fuchs U, Dreier J, Kuhn J, Knabbe C, Birschmann I, Schulz U, Berthold HK, Pilz S, Gouni-Berthold I, Gummert JF, Dittrich M and Borgermann J: Effect of vitamin $\mathrm{d}$ on all-cause mortality in heart failure (evita): A 3-year randomized clinical trial with 4000 iu vitamin d daily. Eur Heart J 38(29): 2279-2286, 2017.

133 Dankers W, Colin EM, van Hamburg JP and Lubberts E: Vitamin $d$ in autoimmunity: Molecular mechanisms and therapeutic potential. Front Immunol 7: 697, 2016.

134 Berridge MJ: Vitamin d deficiency and diabetes. Biochem J 474(8): 1321-1332, 2017

135 Wagner CL, Hollis BW, Kotsa K, Fakhoury H and Karras SN: Vitamin d administration during pregnancy as prevention for pregnancy, neonatal and postnatal complications. Rev Endocr Metab Disord 18(3): 307-322, 2017.
136 Martineau AR, Jolliffe DA, Hooper RL, Greenberg L, Aloia JF, Bergman P, Dubnov-Raz G, Esposito S, Ganmaa D, Ginde AA, Goodall EC, Grant CC, Griffiths CJ, Janssens W, Laaksi I, Manaseki-Holland S, Mauger D, Murdoch DR, Neale R, Rees JR, Simpson S Jr., Stelmach I, Kumar GT, Urashima M and Camargo CA Jr.: Vitamin d supplementation to prevent acute respiratory tract infections: Systematic review and metaanalysis of individual participant data. BMJ 356: i6583, 2017.

137 Garland CF, Kim JJ, Mohr SB, Gorham ED, Grant WB, Giovannucci EL, Baggerly L, Hofflich H, Ramsdell JW, Zeng $\mathrm{K}$ and Heaney RP: Meta-analysis of all-cause mortality according to serum 25-hydroxyvitamin d. Am J Public Health 104(8): e43-50, 2014.

138 Trehan N, Afonso L, Levine DL and Levy PD: Vitamin d deficiency, supplementation, and cardiovascular health. Crit Pathw Cardiol 16(3): 109-118, 2017.

139 Grant WB: Lower vitamin-D production from solar ultraviolet$\mathrm{B}$ irradiance may explain some differences in cancer survival rates. J Natl Med Assoc 98(3): 357-364, 2006.

140 Grant WB, Karras SN, Bischoff-Ferrari HA, Annweiler C, Boucher BJ, Juzeniene A, Garland CF and Holick MF: Do studies reporting ' $U$ '-shaped serum 25 -hydroxyvitamin Dhealth outcome relationships reflect adverse effects? DermatoEndocrinology 8(1): e1187349, 2016.

Received August 29, 2017

Revised October 3, 2017

Accepted October 5, 2017 